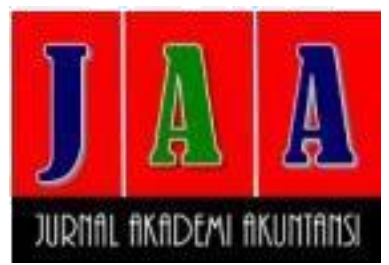

\title{
EFFECT OF SELF-EFFICACY, MOTIVATION ON ENTREPRENEURSHIP, ENTREPRENEURSHIP EDUCATION, AND SOCIAL ENVIRONMENT AGAINST INTEREST IN ENTREPRENEURSHIP ON MICRO, SMALL AND MEDIUM ENTERPRISES BUSINESSES IN SERANG REGENCY
}

Uli Wildan Nuryanto* ${ }_{1}$, Ratih Purnamasaris, Masyhudzulhak Djamil Mzs, Ahmad Hidayat Sutawidjaya, Ahmad Badawi Saluys 3,4\&5 Doctoral Postgraduate Program University Mercu Buana

Jl. Meruya Selatan No. 1 Kembangan, Jakarta Pusat 1,2Sekolah Tinggi Ilmu Ekonomi Banten

Jl. Letnan Jidun No.5c, Lontarbaru, Kec. Serang, Kota Serang, Banten

*Corresponding author: uli.wildan11@gmail.com

Diterima : 08 Oktober 2019

Direview : 09 Oktober 2019

Direvisi : 07 November 2019

Diterima : 22 November 2019

Artikel ini tersedia di website :

$\underline{\text { http://ejournal.umm.ac.i }}$ d/index.php/jaa

\section{ABSTRACT}

The high population growth rate in Serang Regency in the last five years which reached an average rate of $0.77 \%$ made Serang Regency one of the Regencies that contributed to the high rate of population growth in Banten Province which in the last five years reached an average lift of $2,14 \%$. This figure is inversely proportional to the amount of adequate employment, making Serang Regency the Regency with the highest open un-employment rate in Banten Province which reached $12.78 \%$, this causes Banten Province to become the Province with the highest open un-employment rate in Indonesia with number 8,52\% (BPS, 2018). Various efforts were made by the government to tackle un-employment in Serang Regency, one of which was the development of independent community enterprises in the form of entrepreneurship. For this reason, the study seeks to examine indicators that can influence each exogenous and endogenous variable, as well as the influence on the interest in entrepreneurship in Serang regency. Factors that influence the interest in entrepreneurship in this study are divided into two, including internal factors consisting of self-efficacy and motivation for entrepreneurship as well as external factors consisting of entrepreneurship education and social environment. The samples tested were 99 respondents using PLS SEM. From the outer test results found all indicators of each variable have high validity and reliability in describing each of the latent variables while the results of the inner test obtained four hypotheses which showed a significant effect of each predictor variable on the interest in entrepreneurship, with the magnitude the influence of the four variables is $79.8 \%$.

Keywords: Self-Efficacy, Entrepreneurship Motivation, Entrepreneurship Education, Social Environment, Entrepreneurial Interest, Micro, Small and Medium Enterprises of Serang Regency. 


\section{INTRODUCTION}

The phenomenon that occurs due to the limited employment that is inversely proportional to the high rate of population in Serang Regency has caused various kinds of social problems, one of which is the high un-employment rate which reaches $12.78 \%$. Based on data from the statistics center in 2017 , there are more than 500 industries in Serang Regency, which consist of basic metal industry, chemical industry, textile industry, construction industry to various labor-intensive industries. According the number of industries capable of absorbing as many as 546,473 workers consisting of a composition of 367,883 male workers and 178,500 female workers. Whereas in 2018, there was an increase in the number of people working to 574,879 people, an increase of 28,406 people compared to 2017. Compared to August 2017 to August 2018, the number of workforce increased from 628,101 people in August 2017 to 659,042 people in August 2018, which was caused by an increase in the number of working population of 28,406 during that period. The number of unemployed also increased from 81,628 people to 84,163 , while the labor force participation rate increased from $59.95 \%$ to $62.42 \%$ with the increase in the level of labor force participation indicating an additional supply of labor. Comparison of open unemployment rates of Banten Province and Serang Regency between 2017 and 2018 can be seen in the following graph:

Picture 1. Comparison Graphs Un - employment Rate Banten and Serang

Regency

in $2017 \& 2018$.

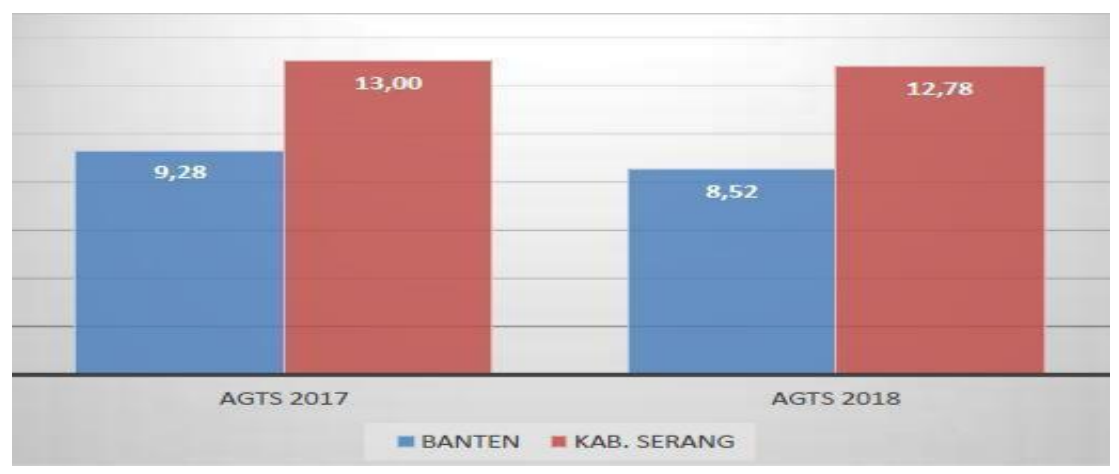

Source: The Central of Statistics Departemen of Serang Regency (2018)

Its shown that in 2018 Serang Regency as the Regency with the largest unemployment rate in Banten Province compared to other Regency and Cities in Banten Province. This is because there are many jobs that attract migrants to enter Serang Regency, especially in the industrial sectors. Many of the migrants entering this job are not all able to be absorbed by the labor market, thus increasing the number of un - employed people in Serang Regency. On the other hand, migrants who enter with higher education levels will find it easier to find 
jobs in Serang Regency. In the structure of the workforce, during the August 2017 to August 2018 period the magnitude of the trend of employment absorption in Serang Regency was the largest in the processing industry sector with 161,660 people or $28 \%$, agriculture, forestry and livestock sector as many as 137,932 people or $24 \%$, trade sector large, retail, and repair of car and motorbike maintenance as many as 92,507 people or $16 \%$ of the total jobs available.

The percentage of the populations working according to the main employment status in Serang Regency in August 2017 to August 2018 is as follows: self-employed (entrepreneur) of 103,942 people (18.08\%), trying to be assisted by temporary workers / paid laborers as many as 62,111 people $(10.80 \%)$, trying to be assisted by permanent workers / paid laborers as many as 12,200 people (2.12\%), workers / employees / employees as many as 255,150 people $(44.38 \%)$, free workers as many as 105,813 people (18.41\%), and family workers / unpaid 35,663 people $(6.20 \%)$ If it is compiled more simply into 2 groups of formal and informal economic activities, where formal activities consist of workers / employees / employees, and those who try to be assisted by permanent workers. While informal groups are selfemployed jobs, trying to be assisted by temporary workers, free workers and family workers. Then the percentage of formal worker groups is 267,350 people $(49.40 \%)$ while the informal group was 307,529 (50.6\%), indicating that informal economic activities became more dominant.

If seen from the composition of the working population according to education, in Serang Regency it is dominated by those with low education (junior high school) of 398,356 people $(69.29 \%)$ then middle level (SMA / SMK) of 147,354 people (25.63\%) and levels high (diploma and undergraduate) of 29,169 people $(5.07 \%)$. It is seen that those who are educated in junior high school or below are most absorbed in employment and generally work as informal workers. Meanwhile, the number of un-employed students in secondary education (SMA / SMK) amounted to 47,896 people $(56.91 \%)$ then low education (junior high school) was 34,948 people $(41.52 \%)$ and higher education 1,319 people $(1.57 \%)$. Those who are graduates of both diploma and undergraduate colleges are more easily absorbed in the labor market so that the graduates are at least un-employed. TPT is based on education, the highest is General High School graduates with 25.34\% then Vocational High School with 22.64\%. This means there is a change where in August 2017, the highest TPT based on education was Vocational High School. To be more clearly seen in the following graph: 
Picture 2 : Graph composition of the population Working, Unemployed and Unemployment Rate (TPT) in Serang Regency, August 2018.

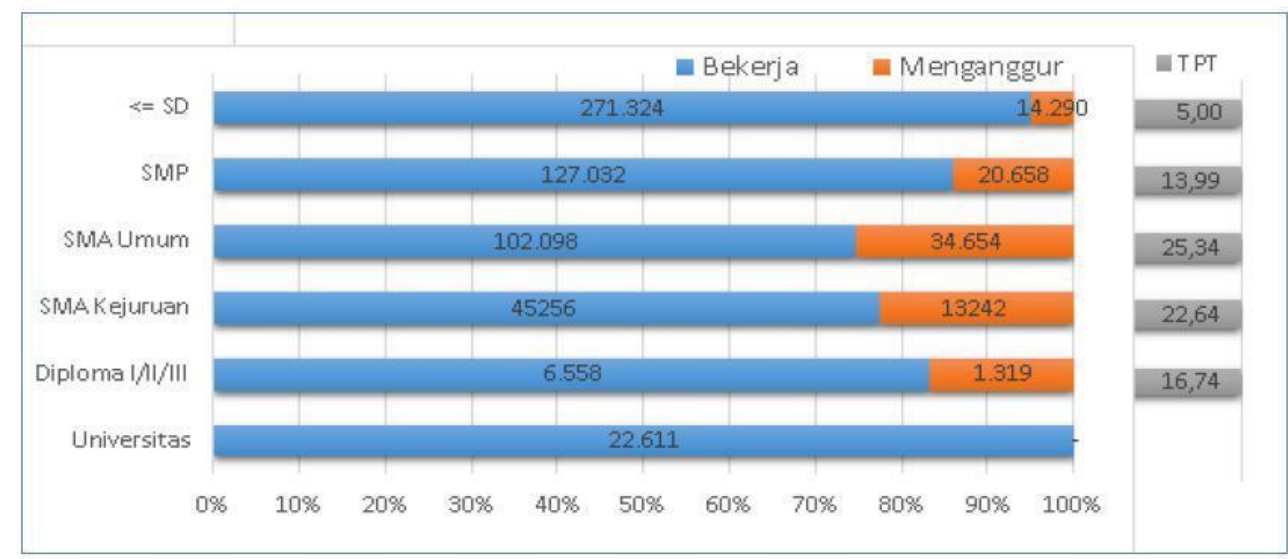

Source: The Central Bureau of Statistics of Serang Regency (2018)

With the number of open unemployment rates as described above, it is necessary to increase employment that is independent and able to absorb labor in large numbers, one of which is entrepreneurship. Given that one of the criteria for open unemployment is those who have not worked but are preparing a business. Given this, it is necessary to increase the awareness and motivation of various stakeholders to foster interest in entrepreneurship among the community. For this reason researchers are trying to dig up information and test hypotheses related to internal factors which consist of variables of self-efficacy and motivation and external factors which consist of entrepreneurship education and social environment whether it is able to influence the interest in entrepreneurship in MSME actors who have already started their business. With the results of the research obtained, it is expected to be able to detect which dominant factors should be focused by related parties in order to increase interest in entrepreneurship

McClelland in Pribadiyanto and Amboningtyas (2016) illustrates that a country becomes prosperous entrepreneur if there are at least $2 \%$ of the total population in the country. While the number of entrepreneurs in Indonesia in 2017 stood at $3.1 \%$ of the total population in Indonesia. This is certainly increased compared to in 2014 the figure was $1.67 \%$ of the total population in Indonesia. However, self-employment ratio of $3.1 \%$ is still lower than in other countries, like the United States 12\%, Japan 11\%, China 10\%, $7 \%$ and Malaysia Singapore $5 \%$. To make Indonesia as the most advanced country in ASEAN, Indonesia should be able to increase its number of entrepreneurs to catch up with the ASEAN countries, that it is absolutely necessary how the role of government as well as all related relevant parties order to increase interest in entrepreneurship among the public. 


\section{LITERATURE}

\subsection{Entrepreneurship}

According to Big Indonesian Dictionary (KBBI), meaning the same as self-employed entrepreneurs, namely intelligent people or gifted to recognize new products, determine how new production, develop operations for the procurement of new products, market, and manage the capital operations. There are two main functions of an entrepreneur, i.e as a planner and as executor. It was agreed that as a planner, an entrepreneur would carry out activities in the form of compiling business units, developing business unit strategies, expressing ideas for the company, and holding and implementing the vision of leadership. Whereas as an implementer an entrepreneur has a role as finding, creating and applying new ideas that are different, imitating and duplicating, imitating and modifying and developing products from product development, technology, image and organization.

In Republic Indonesia Law No. 20 of 2008, the criteria for Micro, Small and Medium Enterprises are divided into micro, small-scale and medium-sized businesses. Which includes micro businesses is a business that has a net worth of Rp. 50 million and not including buildings and business land with the maximum income of Rp. 300 million every year. Small business is a productive economic enterprise that is independent and owned by individuals, or groups and not branches of the main company, owned and become a part of both direct and nondirect from medium-sized businesses, with a net worth of Rp.50 million - Rp. 500 million and the annual income between Rp. 300 million- Rp. 2.5 billion. Mediumsized businesses are productive economic enterprises and are not part of a branch or subsidiary of a central company and become a direct or indirect part of small businesses or large businesses with total assets of Rp. 500 million-Rp. 10 billion and does not include buildings and land of business premises with a total income of Rp. 2.5 billion to Rp. 50 billion.

Entrepreneurship is one of the subject areas to be important and in line with the needs of today's society. Given the potential and benefits, since the 20th century (90s), many scientists who deepen and conduct scientific research related to entrepreneurship and its relationship with economic and psychological (Obschonka, et al., 2010). At present entrepreneurship has a very large relevance in social life given the ongoing increase in the social and economic challenges faced by today's global society. Entrepreneurship encourage the creation of new jobs, and is essential for economic growth in the community and can help reduce poverty (Amoros and Bosma, 2014). For this reason the need for the promotion and development as well as increasing interest in entrepreneurship in the community in order to improve the economy and help the success of today's modern society (Audretsh, 2007).

If it is related to the unemployment rate in Serang Regency, it will be very helpful to reduce the open unemployment rate, given that the number of open un employed for female sex in the August 2017 to August 2018 period has increased 
from $10.82 \%$ to $13.19 \%$ and this shows that the number of female un - employed is higher than male un - employment (12.56\%). This is evidenced by the research of Jenning and Brush (2013), where women will be very motivated to do entrepreneurship given the encouragement of their needs. In addition, in many countries, women have little opportunity to make related decisions about career women in official institutions due to internal and external factors (Sarfaraz, et al., 2014) and the many social challenges that ultimately compel them to become entrepreneurs. In underdeveloped countries and developing countries, the choice to become an entrepreneur is due to motivating factors (Pines, et al., 2010) such as encouraging life in the midst of economic difficulties, breaking away from unemployment, and having experienced disappointment in previous jobs and also due to economic recession (Pogessi, et al., 2016).

\subsection{Interest in Entrepreneurship}

Interest or the intention of entrepreneurship is the determination of someone to become an entrepreneur or entrepreneur. Tubs and Ekeberg (1991) interpret the intention of entrepreneurship as a representation of planned actions to carry out entrepreneurial behavior. While Pramitasari (2017) concluded the interest in entrepreneurship as a determination of someone to start a business that is influenced by the intention of entrepreneurship, so it is very important in increasing the intention of entrepreneurship to be able to increase interest in entrepreneurship. Sardiman (2003) defines interest as a condition that occurs when a person sees traits or transient meanings of situations that are associated with their own desires or needs. This can be elaborated from the research of Mahesa \& Rahardja (2012) which outlines the interest in entrepreneurship as a tendency of the heart in a person to create a business which then organizes, regulates, carries risks and develops the business created by itself. In this study, 5 indicators were used to measure interest in entrepreneurship which refers to the research of Kadarsih, et al (2013), and Setyowati (2013), including choosing entrepreneurship rather than working for other people, choosing careers as entrepreneurs, planning to start a business, improve social status as entrepreneurs and get better income.

\subsection{A Self-efficacy}

Bandura (1997) defines self-efficacy as an individual's belief in his ability to carry out tasks or perform actions needed to achieve certain results. Luthans (2008) illustrates that self-efficacy can encourage one's performance in various fields including one of them is entrepreneurship. By Karen, in opening a business, selfconfidence is needed, on its ability so that the business can succeed. This was confirmed by Robbins (2007) who stated that self-identification in social cognitive theory is something that refers to the individual's belief that he is capable of carrying out a task. In the context of entrepreneurship, it can be concluded that selfefficacy is a belief in an entrepreneur in his ability to achieve his 
entrepreneurial goals. In this study researchers used 5 indicators to measure selfefficacy referring to the research of Andika \& Madjid (2012), Kadarsih, et al (2013) and Paramitrasari (2019), among others: self-confidence in managing business, human resource leadership, mental maturity in starting business, has firm confidence in starting a business and the ability to start a business.

\subsection{Motivation on Entrepreneurship}

Gibson (2006) in Dewi \& Haryanto (2017) describes motivation as a force that encourages someone who raises and directs behavior to achieve goals. Moon motivation is a thing that looks and can be observed, but something that can be concluded due to the existence of a visible behavior. Whereas in its context with entrepreneurship, Baron (2007) in Sumadi and Sulistiawati (2017) states that motivation in entrepreneurship includes motivation that is directed towards achieving entrepreneurial goals such as goals involving the introduction and exploitation of business opportunities. Motivation to develop a new business is needed not only to have confidence but also in terms of the ability to succeed and the ability to access information related to entrepreneurial opportunities. This study uses 5 indicators to measure entrepreneurship motivation which refers to the Mahananani \& Sari (2018), Tuskeroh (2013), and Iswandari (2014) studies, among others: self-confidence, innovative and creative, have leadership, effective and efficient and oriented to future.

\subsection{Entrepreneurship Education}

Entrepreneurship education began to develop in the early 1970s, and in recent years, Entrepreneurship Education has developed very rapidly in various countries, even efforts to improve Entrepreneurship Education have increased significantly as in the UK (Levie, 1999), Spain and the Netherlands (Koch, 2002), Iran (Arasti, et al, 2012) and Malaysia (Hamzah, et al 2016). So it is not surprising that entrepreneurship has become one of the fastest growing subjects in universities and universities (Solomon, et al, 2002; Vesper and Gartner, 1999). Entrepreneurship education focuses on developing entrepreneurship knowledge, capacity, skill and entrepreneurial attitudes and intentions that are in line with economic needs. Levie and Autio (2008) argue that entrepreneurial education is a powerful suggestion in promoting entrepreneurial growth and development.

The results of research conducted by Fox and Pennington (2009) show that entrepreneurship education has a positive impact on economic development through new businesses that create additional jobs and income. This study uses 5 indicators that are used to measure entrepreneurship education variables that refer to Pramitasari's research (2019), among others: having the courage to take risks in entrepreneurship, having the power of creation and imagination, prioritizing cost savings, having high ability to assess opportunities and have ways analysis, systematic and appropriate methodology in entrepreneurship. 


\subsection{Social Environment}

External factors have a strong influence in shaping the individual characteristics of a person, including in influencing one's interest in entrepreneurship. The external factors are elements that come from the surrounding environment such as family environment, business environment, physical environment, socio-economic environment and others (Koranti, 2013). Purwinarti (2006) illustrates that one of the factors driving a person to become an entrepreneur is parental refugee. Many individuals obtain education and experience from the business built by their families and their family environment greatly influences their children's entrepreneurial interests. In addition, the social environment contributes highly to the interest in entrepreneurship.

Parents' work background and entrepreneurial experience transmitted from parents also include factors that can influence the interest in entrepreneurship, because the family is the first social group in human life as a place to learn and express themselves as social humans in the interaction relationship with their groups. This study uses four indicators that are used to measure social environment variables which refer to the research of Koranti (2013) and Purwinarti (2006), among others: community work around the place of residence, profession of friends, background of parents and social status.

\section{Research methods}

This research was conducted in Serang which became one of the Regencies in Banten Province which had the highest open un-employment rate in Banten Province. Serang Regency has a business unit of 26,909 business units spread across 34 sub-Regencys. The researcher used 99 resonden samples from 7 sub-Regencys using the purposive side method. Instrument research in the form of questionnaires and interviews. Analysis using PLS SEM method to measure the influence of indicators on exogenous variables also on endogenous variables whose models have been determined by the researcher. PLS was first developed by Herman O.A. Wold in the 1960s, the PLS method was not based on many assumptions or conditions such as normality and multicollinearity tests. Another advantage is that data does not have to be normally multivariate, even indicators with ordinal data scales, intervals to ratios can be used. Another advantage is the size of the sample that does not have to be large, with a minimum of 30 data, it can be analyzed using PLS. With the limitations of time, energy and costs, the researchers limited the number of samples used in this study to 99 respondents. The research framework is as follows: 


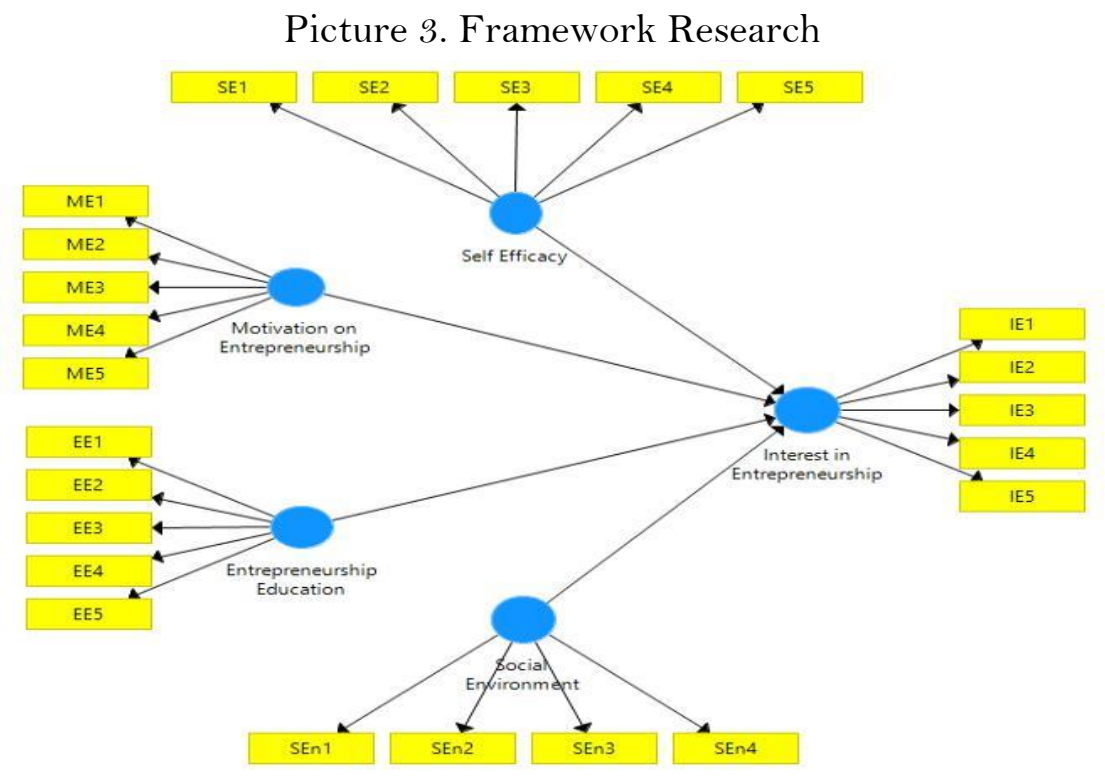

The Equation Model as follows:

$\mathbf{Y}=\mathbf{B}_{1} \mathbf{X}_{1}+\mathbf{B}_{2} \mathbf{X}_{2}+\mathbf{B}_{3} \mathbf{X}_{3}+\mathbf{B}_{4} \mathbf{X}_{4}+\mathbf{e}$

$\mathrm{Y}=$ Variable interest in entrepreneurship

$\mathrm{X}_{1}=$ Self efficacy variable

$\mathrm{X}_{2}=$ Entrepreneurial Motivation Variables

$\mathrm{X} 3$ = Entrepreneurship Education Variable

$\mathrm{X} 4=$ Social Environment Variables

This study uses four hypotheses to be tested, including:

H1: Self-efficacy has a significant effect on the interest in entrepreneurship among Micro, Small and Medium Enterprises entrepreneurs in Serang Regency.

H2: Motivation for entrepreneurship has a significant effect on the interest in entrepreneurship among Micro, Small and Medium Enterprises entrepreneurs in Serang Regency.

H3: Entrepreneurship education has a significant effect on the interest in entrepreneurship among Micro, Small and Medium Enterprises entrepreneurs in Serang Regency.

H4: The social environment has a significant effect on the interest in entrepreneurship among Micro, Small and Medium Enterprises entrepreneurs in Serang Regency.

\section{RESULTS \& DISCUSSION}

\subsection{Descriptive Test Results}

Descriptive test results against 99 respondents spread in 7 Regencys with a sample of Binuang Regency 15 respondents (15.15\%), Carenang 15 respondents (15.15\%), Cikande 15 respondents (15.15\%), Kibin 15 respondents $(15,15 \%)$, helter 9 respondents $(9.09 \%)$, Tanara 15 respondents 
$(15.15 \%)$ and Tirtayasa 15 respondents (15.15\%). As for the distribution of business groups from all 99 respondents is as follows, a business group of buildings as much as 3 respondents (3.03\%), processing industry as much as 15 respondents (15.15\%), a business group of services as much as 6 respondents $(6.06 \%)$, finance, leasing and business services as one of the respondents (1.01\%), trade, hotels and restaurants as much as 16 respondents (16.16\%), mining and quarrying as much as 9 respondents $(9.09 \%)$ and the highest is group agriculture, livestock, forestry and fisheries business as many as 49 respondents $(49.49 \%)$.

Total absorption of labor that can be produced by each business group of 99 respondents is as follows, a business group of building as many as 9 people $(3.27 \%)$, processing industries as many as 59 people $(21.45 \%)$, a business group of services as many as 15 people (5.45\%), finance, leasing and business services as much as $6(2.18 \%)$, trade, hotels and restaurants as many as 27 people $(9.82 \%)$, mining and quarrying as many as 40 people $(14,55 \%)$, the largest is the group of agriculture, livestock, forestry and fisheries as many as 119 people (43.27\%).

The majority of respondents in this study were male as many as $64.65 \%$ while the rest were female at $35.35 \%$. Based on the criteria of age, the majority of respondents aged $40-45$ years old as much as $35.35 \%$, age 36 40 years as much as $25.25 \%$, age $46-50$ years as many as $16.26 \%$, age $30-35$ years as much as $14.14 \%$, under 30 years of as much as $5.05 \%$ and the remaining $4.04 \%$ are above 50 years. Based on the Education criteria, the majority of respondents with high school education were $32.32 \%$, followed by SMP as much as $29.29 \%$, SMK as much as $25.25 \%$, SD as much as $11.11 \%$, and diplomas and scholars each by $1.01 \%$.

\subsection{Outer Results Analysis}

\subsubsection{Convergent Validity}

The test results of the convergent validity of self-efficacy variables each SE1, SE2, SE3, SE4 and SE5 are 0.811, 0.704, 0.908, 0.760 and 0.839. The Indicators for entrepreneurship motivation variable respectively ME1, ME2, ME3, ME4 and ME5 at 0.746, 0.823, 0.694, 0.708 and 0.685. Indicators for Entrepreneurship Education variables each EE1, EE2, EE3, EE4 and EE5 amounted to 0.718, 0.657, 0.875, 0.730 and 0.791. Indicators for the variable social environment of each SEn1, SEn2, SEn3 and SEn4 amounted to $0.861,0.836,0.827$ and 0.827 whereas for indicators of variable interest in entrepreneurship each IE1, IE2, IE3, IE4 and IE5 amounted to $0.733,0.821,0.750,0.809$ and 0.870 . From the results of convergent validity, the overall indicator has a value of loading factors above 0.60 which illustrates that each indicator is able to build its own construction. 


\subsubsection{The Discriminant Validity}

The test results of discriminant validity of each indicator shows each of the indicators of the variables of self-efficacy, motivation, selfemployment, entrepreneurship education and social environment has a value of cross loading of larger ones to construct respectively compared to the construct others, illustrating that each indicators able to explain and establish the latent constructs.

\subsubsection{Average Variance Extracted (AVE)}

The AVE value shows the variance value for each indicator in the construct captured by the variable more than the variance caused by measurement errors. From the results of the analysis obtained AVE values for each construct greater than 0.50 .

1. The Value Table of Average Variance Extracted (AVE)

\begin{tabular}{|l|l|}
\hline \multicolumn{1}{|c|}{ Construct } & AVE \\
\hline Self-efficacy & 0,652 \\
\hline $\begin{array}{l}\text { Entrepreneurship } \\
\text { Motivation }\end{array}$ & 0,540 \\
\hline $\begin{array}{l}\text { Entrepreneurship } \\
\text { Education }\end{array}$ & 0,574 \\
\hline Social Environment & 0,702 \\
\hline Entrepreneurial Interest & 0,637 \\
\hline
\end{tabular}

\subsubsection{Composite Reliability}

The expected composite reliability value from the test results is above 0.70 which illustrates each indicator has a high consistency to measure latent variables. The results of the study show that each construct has a composite reliability value above 0.70 which signifies the consistency of the construct to measure high latent variables.

2. The Value Table of Composite Reliability (CR)

\begin{tabular}{|l|c|}
\hline \multicolumn{1}{|c|}{ Construct } & \multicolumn{1}{|c|}{$\begin{array}{c}\text { Composite } \\
\text { Reliability }\end{array}$} \\
\hline Self-efficacy & 0,903 \\
\hline Entrepreneurship Motivation & 0,854 \\
\hline Entrepreneurship Education & 0,870 \\
\hline Social Environment & 0,904 \\
\hline Entrepreneurial Interest & 0,898 \\
\hline
\end{tabular}

\subsubsection{Cronbach's Alpha}

The expected Cronbach's Alpha value from the test results is above 0.70 which illustrates that each indicator has a high consistency in measuring 
latent variables. The results of the study show that each construct has a Cronbach's Alpha value above 0.70 which signifies the consistency of construct to measure high latent variables.

3. The Value Table of Cronbach's Alpha

\begin{tabular}{|l|c|}
\hline \multicolumn{1}{|c|}{ Construct } & Cronbach's Alpha \\
\hline Self-efficacy & 0,864 \\
\hline $\begin{array}{l}\text { Entrepreneurship } \\
\text { Motivation }\end{array}$ & 0,786 \\
\hline Entrepreneurship Education & 0,811 \\
\hline Social Environment & 0,858 \\
\hline Entrepreneurial Interest & 0,857 \\
\hline
\end{tabular}

\subsection{The results of the model Inner Analysis}

\subsubsection{Goodness of fit test}

The results of the goodness of fit test obtained $\mathrm{R} 2$ values for constructing entrepreneurial interest of 0.798 which can be interpreted that self-efficacy, entrepreneurship motivation, entrepreneurship education, and social environment have an influence of $79.8 \%$ on interest in entrepreneurship while the remaining $20.2 \%$ is influenced by the other variables.

4. The Value Table of R-Square

\begin{tabular}{|l|c|}
\hline ConstructR-Square & \\
\hline Entrepreneurial Interest & 0,798 \\
\hline
\end{tabular}

\subsubsection{The Coefficient Values (Original Sample), Standard Error and T- Statistics}

To answer the existing hypothesis, we see the significance of the influence between construct independent and dependent on the significance level of $5 \%$. The results of the T-Statistics value are as follows:

5. The Value Table of Coefficients value (Original Sample),

Standard Error and T-Statistics

\begin{tabular}{|l|c|c|c|c|l|}
\hline \multicolumn{1}{|c|}{ Influence Test } & $\begin{array}{c}\text { Original } \\
\text { Sample } \\
(\mathbf{O})\end{array}$ & $\begin{array}{c}\text { Standard } \\
\text { Error } \\
(\text { STERR })\end{array}$ & $\begin{array}{c}\text { T } \\
\text { Statistic } \\
(\mathbf{O} / \text { STE } \\
\mathbf{R R})\end{array}$ & $\begin{array}{c}\mathbf{P} \\
\text { Values }\end{array}$ & Conclusion \\
\hline $\begin{array}{l}\text { Self Efficacy } \rightarrow \text { Entrepreneurial } \\
\text { Interest }\end{array}$ & 0,378 & 0,196 & 6,930 & 0,000 & Significant \\
\hline
\end{tabular}




\begin{tabular}{|l|r|r|r|r|l|}
\hline $\begin{array}{l}\text { Entrepreneurial motivation } \rightarrow \\
\text { Entrepreneurial Interest }\end{array}$ & 0,154 & 0,101 & 5,525 & 0,000 & Significant \\
\hline $\begin{array}{l}\text { Entrepreneurship Education } \rightarrow \\
\text { Entrepreneurial Interest }\end{array}$ & 0,255 & 0,150 & 5,703 & 0,000 & Significant \\
\hline $\begin{array}{l}\text { Social environment } \rightarrow \\
\text { Entrepreneurial Interest }\end{array}$ & 0,095 & 0,104 & 4,920 & 0,000 & Significant \\
\hline
\end{tabular}

Equation Model:

$\mathrm{Y}=0,378 \mathrm{X}_{1}+0,154 \mathrm{X}_{2}+0,255 \mathrm{X} 3+0,095 \mathrm{X}_{4}$

Based on the test results on the value coefficient, standard error and $\mathrm{T}$ statistic, the coefficient value for the variable self efficacy was 0.378 while the entrepreneurship motivation variable was 0.154, the Entrepreneurship Education variable was 0.255 and the Social Environment was 0.095. This shows that from the four variables above, the variable self-efficacy has the largest coefficient value which illustrates that the four variables tested on the variable interest in entrepreneurship are very dominantly influenced by the variables of self-efficacy. While the magnitude of the influence that can be explained by the four independent variables is $79.8 \%$ as shown in table 4 with an R-square value of 0.798. The results of the statistical $\mathrm{T}$ test for each variable of self-efficacy, entrepreneurship motivation, entrepreneurship education and social environment obtained values of 6.930 then 5.525, 5.703 and 4.920. This shows that each of the statistical $\mathrm{T}$ values is above the Z-Score 1,96 which explains that each variable has a significant influence on the interest in entrepreneurship.

From the results of testing the first hypothesis where the variables of self-efficacy have a significant effect on the interest in entrepreneurship, this result is in line with the research of Andika \& Madjid (2012) and Setyowati (2013) who get results that will only be formed if they have confidence and confidence. the ability and success of starting and running an entrepreneur with all the risks involved. From the indicators used to measure latent variables, namely self-confidence in managing business, leadership of human resources, mental maturity in starting a business, having firm confidence in starting a business and the ability to start a business, all indicators contribute to latent variables. If someone does not believe in the abilities they have, then the possibility will be very small for the person to be interested in entrepreneurship. Luthans (2008) in his Nine Meta Analysis found that self-confidence will drive a person's performance in various fields including interest in entrepreneurship.

While self-confidence according to Kreitner and Kinicki in Engko (2006) is a person's belief about the opportunity to succeed in achieving certain goals that come from high self-confidence to achieve his career in the future. The results of this hypothesis indicate that respondents as Small and Medium Enterprises (MSMEs) entrepreneurs in Serang Regency have very high confidence in starting 
and running their businesses, this will encourage them to be ready to face all the risks in the business full of challenges.

The second hypothesis test results related to the influence of entrepreneurial motivation on the interest in entrepreneurship have a significant influence, this is in line with the research of Koranti (2013) and Dewi \& Haryanto (2017), where motivation is the background of individuals doing something to achieve certain goals, in the context of entrepreneurship, a person who has the motivation for entrepreneurship will use and mobilize all of his potential to achieve success in entrepreneurship. The five indicators used to measure entrepreneurship motivation are self-confidence, innovative and creative, have leadership spirit, are effective and efficient and are oriented towards the future, all of these indicators have values that build entrepreneurial motivation variables. The observations of researchers towards respondents, all respondents were very oriented towards the future and the continuity of entrepreneurship carried out and strive to continue to innovate and improve to get a better change from the field of business that it runs. This has the potential for the advancement of entrepreneurs in Serang Regency in order to grow more creatively in the future.

The third hypothesis test between entrepreneurship education variables on the interests of entrepreneurship has a significant influence, this is in line with the research of Yunio \& Hodayatullah (2018) and Anggraeni \& Nurcaya (2016) which states that education will greatly influence the interest in entrepreneurship, if someone gets an education about entrepreneurship will increasingly understand the benefits of being an entrepreneur and increasingly interested in becoming entrepreneurs. Respondents interviewed by the researcher stated that they had received training and guidance from related institutions related to empowering Micro, Small and Medium Enterprises and most importantly also got entrepreneurial support from people who had already started entrepreneurship and pursued business, thus making them role models in running their entrepreneurship.

Hypothesis test results of social environment variables on interest in entrepreneurship have a significant influence, this result is in line with research conducted by Koranti (2013) and Setyowati (2013) where the emergence of interest in entrepreneurship cannot be separated from social influences such as family environment, work background of parents and surrounding environment. The condition of parents and the surrounding environment will be a figure for someone because interest in entrepreneurship will arise in someone if the environment supports because interest will be formed from the family environment and entrepreneurship education can take place early in the family environment. The surrounding environment such as friends will also influence someone in making a decision to become an entrepreneur, with a social environment consisting of entrepreneurs who will encourage someone to follow the field that has been undertaken by their friends and entrepreneurs who have successfully carried out their profession. The results of observations of researchers 
towards respondents, it was found that the number of environments around the respondents who run the profession as entrepreneurs either because of the drive to maintain their survival or because of other encouragement will be very potential for Micro, Small and Medium Enterprises actors to be able to enjoy their business because they have the same perception of their profession, this is an added value for the development of Micro, Small and Medium Enterprises.

Based on recapitulation data from Diskoperindag of Serang Regency in 2018, the number of business units of Micro, Small and Medium Enterprises in 2018 was 26,909 business units divided into 9 business groups, with employment of 75,530 people. This result is very supportive of the Banten Provincial government program specifically in reducing social inequality and poverty rates by reducing the number of open un-employment. When viewed more in depth from the side of the Micro, Small and Medium Enterprises business group in Serang Regency based on the number of business units, the first three major business groups were trading, hotel and restaurant sectors totaling 10,882 business units, and 5.017 manufacturing business units and the three agricultural, forestry and fisheries sectors as many as 3,956 business units. If it is grouped based on the amount of labor absorption, then the first order is the agricultural sector with a labor absorption of 20,242 people, the second is the manufacturing industry sector of 18,959 people and the third is the trade, hotel and restaurant sector with 18,065 people. Whereas if sorted by the amount of turnover per year, the trade, hotel and restaurant sector is the highest with a turnover of Rp. 895,338,428,000,

- followed by the manufacturing industry sector of Rp. 643,525,653,072, - and the three sectors of agriculture, livestock, forestry and fisheries amounted to Rp. 401,891,802,000. The total turnover per year of all business groups is Rp. 2,877 trillion (Dinas Koperasi Perindustrian dan Perdagangan Kabupaten Serang, 2019).

\section{CONCLUSION}

Based on the results of the research and discussion above, the researcher can draw conclusions as follows:

1. Each indicator of self-efficacy variables, entrepreneurship motivation, entrepreneurship education and social environment has a high validity and reliability of which is reflected from each of the value of convergent validity, discriminant validity, AVE, reliability and Cronbachs alpha compositing;

2. From the regression equation the value of the coefficient values of each variable has a positive effect on the variable interest in entrepreneurship, with the highest coefficient value indicated by the variable self-efficacy of 0.378 which describes the dominant effect of the variable self-efficacy;

3. The value of the $\mathrm{T}$ statistic of each hypothesis shows a greater value than the critical $\mathrm{T}$ value which illustrates the significant influence of each predictor variable on the variable interest in entrepreneurship. The magnitude of the 
effect produced by the four predictor variables is $79.8 \%$ while the remaining $20.2 \%$ are other variables not examined in this study;

4. Government support is needed in relation to providing entrepreneurship education through technical guidance, training and seminars aimed at increasing entrepreneurial knowledge of Micro, Small and Medium Enterprises actors and encouraging innovation and increasing creativity of Micro, Small and Medium Enterprises so that in the future the Micro, Small and Medium Enterprises actors can diversify their businesses which will have an impact on increasing employment capacity so as to reduce the unemployment rate in Serang Regency.

\section{REFERENCES}

Amoros, J.E. and Bosma, N. (2014) "Global Entrepreneurship Monitor. 2013 Global Report. Fifteen years of assessing entrepreneurship across the globe”. (ISBN: 978-1-939242-04-4).

Andika \& Madjid, 2012. Analisis Pengaruh Sikap, Norma Subyektif, dan Efikasi Diri Terhadap Intensi Berwirausaha Pada Mahasiswa Fakultas Ekonomi Universitas Syiah Kuala (Studi Pada Mahasiswa Fakultas Ekonomi Universitas Syiah Kuala). Eco-Entrepreneurship Seminar dan Call for Paper "Improving Performance By Improving Environment 2012 Fakultas Ekonomi Universitas Negeri Semarang.

Anggraeini, D., A., L., \& Nurcaya, I., 2016. Peran Efikasi Diri Dalam Memidiasi Pengaruh Pendidikan Kewirausahaan Terhadap Niat Berwirausaha. EJurnal Manajemen UNUD. 5,4. 2424-2453.

Arasti, Z., Falavarjani, M.K. and Imanipour, N. (2012), "A study of teaching methods in entrepreneurship education for graduate students", Higher Education Studies, Vol. 2 No. 1, pp. 2-10.

Audretsch, D. B. (2007) “The entrepreneurial society. Oxford”, England: Oxford University Press.

Badan Pusat Statistik Kabupaten Serang, 2018. Keadaan Ketenagakerjaan Kabupaten Serang Agustus 2018. No 01/03604/Th II, Desember 2018.

Bandura, Albert. 1977. Self Efficacy Toward a Unfying Theory of Behavioural Change. Journal of Phycological Vol. 84, No.2.

Dewi, S., N., \& Haryanto, A., T., 2017. Dampak Keputusan Berwirausaha Dengan Lingkungan Sosial dan Pendidikan Formal Pada Motivasi Berwirausaha. Jurnal Perilaku Dan Strategi Bisnis. 5, 1. 109-1 16.

Engko, Cecilia. 2006. Pengaruh Kepuasan Kerja Terhadap Kinerja Dengan Self Esteem dan Self Efficacy Sebagai Variabel Interverning. Simposium Nasional Akuntansi 9 Padang.

Fox, J.L. and Pennington, K. (2009), "The effect on economic development of an entrepreneurship program at a North Carolina community college", Journal of Applied Research in the Community College, Vol. 16 No. 2, pp. $47-51$. 
Hamzah, H., Yahya, Z., Sarip, A.G. and Mohd Adnan, Y. (2016), "Impact of entrepreneurship education programme (EEP) on entrepreneurial intention of real estate graduates", Pacific Rim Property Research Journal, pp. 1-13.

Iswandari, A., 2013. Pengaruh Motivasi Intrinsik, Pengetahuan Kewiraushaan, dan Kepribadian Terhadap Minat Berwirausaha Pada Siswa SMKN 12 Surabaya. Jurnal Ekonomi Pendidikan dan Kewirausahaan. 1, 2. 152-162.

Jennings, J. E., \& Brush, C. G. 2013. Research on women entrepreneurs: challenges to (and from) the broader entrepreneurship literature? Academy of Management Annals, 7(1): 663-715.

Kadarsih, et al., 2013. Faktor-faktor yang Mempengaruhi Minat Berwirausaha Pada Mahasiswa Program Studi Pendidikan Ekonomi FKIP UNS. Jupe UNS, 2, 1, 95-106.

Koch, L.T. (2002), "Theory and practice of entrepreneurship education: a German view".

Koranti, K., 2013. Analisis Pengaruh Faktor Eksternal dan Internal Terhadap Minat Berwirausaha. Proceeding PESAT (Psikologi, Ekonomi, Sastra, Arsitektur dan Teknik Sipil). 5. 1-8.

Levie, J. (1999), "Entrepreneurship education in higher education in England: a survey", the Department for Employment and Education.

Levie, J. and Autio, E. (2008), "A theoretical grounding and test of the GEM model”, Small Business Economics, Vol. 31 No. 3, pp. 235-263.

Luthans, F., 2008. Organizational Behavior. Mc Graw-Hills Companies, Inc. New York.

Mahananani, E., dan Sari, B., 2018. Faktor-Faktor yang Mempengaruhi Minat Berwirausaha Mahasiswa Fakultas Ekonomi Universitas Persada Indonesia Y.A.I. Ikraith-Humaniora. 2, 2. 3 1-40.

Mahesa, A., D., Rahardja, E., 2012. Analisis Faktor-Faktor Motivasi yang Memengaruhi Minat Berwirausaha. Diponegoro Journal of Management. 1(1), 130-137.

Obschonka, M., Silbereisen, R. K. and Schmitt-Rodermund, E. (2010) "Entrepreneurial intention as developmental outcome", Journal of Vocational Behavior, Vol. 77, No. 1, pp 63-72.

Pines, A. M., Lerner, M., \& Schwartz, D. 2010. Gender differences in entrepreneurship: equality, diversity and inclusion in times of global crisis. Equality, Diversity and Inclusion: An International Journal, 29(2):186-198.

Poggesi, S., Mari, M., \& De Vita, L. 2016. What's new in female entrepreneurship research? Answers from the literature. International Entrepreneurship and Management Journal, 12(3): 735-764.

Pramitasari, T., D., 2019. Peningkatan Intensi Berwirausaha Dikalangan Mahasiswa. Universitas Abdurahman Saleh Situbondo. 1-15. 
Pribadiyanto, A., dan Amboningtyas, D., 2017. Influence Of Ability, Socio Demography, Self Efficacy, And Minimnya Employment Work On Entrepreneurship In Village Community Pringapus Sub District Pringapus Semarang. Journal of Management. Vol. 3, No. 3.

Robbins. 2007. Perilaku Organisasi: Konsep, Kontroversi dan Aplikasi. Jiilid 1. Jakarta: Prenhallindo.

Sardiman, A., M., 2003. Interaksi dan Motivasi Belajar Mengajar. Jakarta: PT. Raja Grafindo Persada.

Sarfaraz, L., Faghih, N., \& Majd, A. A. 2014. The relationship between women entrepreneurship and gender equality. Journal of Global Entrepreneurship Research, 4(1), 6.

Setyowati, D., I., 2013. Pengaruh Pekerjaan Orang Tua dan Keyakinan Diri Terhadap Minat Berwirausaha Siswa di SMK Negeri 10 Surabaya. Jurnal Ekonomi Pendidikan dan Kewirausahaan. 1, 2. 121-129.

Solomon, G.T., Duffy, S. and Tarabishy, A. (2002), "The state of entrepreneurship education in the United States: a nationwide survey and analysis", International Journal of Entrepreneurship Education, Vol. 1 No. 1, pp. 65-86.

Sumadi ., A., R., dan Sulistyawati, E., 2017. Pengaruh Sikap, Motivasi, dan Lingkungan Terhadap Niat Berwirausaha. E-Jurnal Manajemen Unud. 6, 2. 1007-1029.

Tubs dan Ekeberg. 1991. The Roles of Intentions in Work Motivation: Implications for goal setting theory and research. Academy of Management Review Vol 16.

Tuskeroh, 2013. Pengaruh Motivasi dan Mental Berwirausaha Pada Mahasiswa Akuntansi Universitas Maritim Raja Ali Haji. Fakultas Ekonomi Universitas Maritim Raja Ali Haji. 1-17.

Presiden Republik Indonesia. Undang-Undang Republik Indonesia Nomor 20 Tahun 2008 Tentang Usaha Mikro, Kecil dan Menengah.

Vesper, K.H. and Gartner, W.B. (1999), "University entrepreneurship programs”, Lloyd Greif Center for Entrepreneurial Studies, Marshall School of Business, University of Southern California, Los Angeles, CA.

Yunio, E., R., \& Hidayatullah, D., S., 2018. Pengaruh Lingkungan Keluarga, Kepribadian dan Pendidikan Terhadap Minat Berwirausaha (Studi Pada Mahasiswa Program Studi MBTI Universitas Telekom Tahun AKademik 2016/2017). E-Proceeding of Management. 5,2. 1901-1909. 